\title{
PROTECTING DIGITAL PLATFORM USERS BY MEANS OF PRIVATE INTERNATIONAL LAW
}

\author{
LA PROTECCIÓN DE USUARIOS DE PLATAFORMAS \\ DIGITALES POR MEDIO DEL DERECHO \\ INTERNACIONAL PRIVADO
}

\author{
ILARIA PRETELLI \\ Swiss Institute of Comparative Law \\ Recibido: 15.12.2020 / Aceptado: 12.01.2021 \\ DOI: https://doi.org/10.20318/cdt.2021.5971
}

\begin{abstract}
Abstrac: The present article offers perspectives on the possible adaptation of traditional connecting factors to the digital space. It analyses cases that pit platform users against each other and cases that pit platform users against the digital platform itself. For the first set of cases, reliable guidance is offered by the principle of effectiveness. The enforcement of court decisions in cyberspace is often necessary and also plainly sufficient to render justice. Enhanced protection of weaker parties is advocated, both in tortious (favor laesi) and contractual liability (protection of the weaker party), in line with the most recent achievements in human rights due diligence. Protection clauses leading to destination-based labour standards would be a welcome step forward. Protection of users also offers guidance for the shaping of private international law rules governing disputes between users and the platform.

Keywords: Connecting factors, Principle of Effectiveness, Favor Laesi, Tortious liability, Party autonomy, Consumer contracts, B2B relations, Digital platforms.

Resumen: El presente artículo ofrece perspectivas sobre las posibles adaptaciones de los puntos de conexión tradicionales al espacio digital. Proporciona análisis de casos que enfrentan a los usuarios de la plataforma entre sí y casos que enfrentan a los usuarios de la plataforma con la propia plataforma digital. Para el primer conjunto de casos, el principio de eficacia y el de favor laesi ofrecen una orientación fiable. La colaboración de plataformas digitales para permitir la ejecución de decisiones judiciales en el ciberespacio se considera necesaria y suficiente para garantizar el acceso efectivo a la justicia. En cuanto al segundo, se aboga por una mayor protección de las partes más débiles, en consonancia con los logros más recientes de debida diligencia en materia de derechos humanos. Las cláusulas de protección que conducen estándares de trabajo basados en el destino representarían un paso adelante positivo.
\end{abstract}

Palabras clave: puntos de conexión, principio de efectividad, Favor Laesi, responsabilidad extracontractual, autonomía de las partes, relaciones B2B, plataformas digitales.

Summary: I. Introduction. II. Litigation Between Platform Users. 1. The Importance of Effectiveness and the Role of the Place of Enforcement. 2. Favor Laesi. A) Favor Laesi in Contract Law. B) Favor Laesi in Working Services. III. Relations Between a User and a Platform Exercising Decisive Control. 1. When the Platform Exercises Decisive Control. 2. When the Platform Does not Exercise Decisive Control. IV. Some Conclusions. 


\section{Introduction}

1. When I pronounce the word Future, the first syllable already belongs to the past" a Polish poem reminds us ${ }^{1}$.

2. "This "already past" future is difficult to fully understand, let alone regulate. Digital platforms are often accused of having disruptive effects on many of the world's human societies and on society as a whole ${ }^{2}$. And since society is almost synonymous with law - because one cannot exist without the other - , digital platforms are also disruptive of the law.

3. The most disruptive effect consists in what has been described as the "functional sovereignty" enjoyed by digital firms. In the first years of the new millennium, nation states were taken by surprise and were unprepared for the task of governing the rise of the tech oligopoly of digital platforms. High courts have been the first to react to the existing legal vacua that have boosted digital platforms into the present monopolies and oligopolies ${ }^{4}$. The CJEU and the Swiss Supreme Courts have tried unilateral ways to challenge the use - and abuse - of freedom of establishment to practise tax avoidance tactics ${ }^{5}$. If it weren't tragic, it would seem ironic that companies celebrating cyberspace and its absence of borders - connecting the world - have happily taken advantage of the territorial scope of application of tax laws.

4. Activities carried out on the web have long benefitted from law-free spaces that are inaccessible to rules with a precise territorial scope. This has caused the well-known inequalities, both vertically and horizontally. Horizontally in terms of competition law infringements ${ }^{6}$ and vertically for many reasons including the impoverishment of the welfare state, which is endangering its long-term survival. Adaptation of the present tax rules to the digital economy is only a matter of time ${ }^{7}$. Meanwhile, however, monopolies and oligopolies are already there and are acknowledged as the only possible gatekeepers of their own market ${ }^{8}$.

1 "The three oddest words", by Wislawa Szymborska, translated by S. Baranczak \& C. Cavanagh. The poem goes on to say "When I pronounce the word Silence, I destroy it./ When I pronounce the word Nothing, I make something no non-being can hold". The present article maintains the oral text of the presentation given to the University Carlos III in the framework of the Congress "Legal Tech" (Madrid, 16 November 2020).

${ }^{2}$ See T. Rodríguez de las Heras Ballell, "Legal challenges of artificial intelligence: modelling the disruptive features of emerging technologies and assessing their possible legal impact", Uniform Law Review, June 2019, pp. 302-314; "The Legal Anatomy of Electronic Platforms: A Prior Study to Assess the Need of a Law of Platforms in the EU", The Italian Law Journal, 2017 and "Rules for a Platform Economy: A Case for Harmonisation to Counter "Platform Shopping" in the Digital Economy", in I. Pretelli (ed), Conflict of Laws in the Maze of Digital Platforms, Genève / Zurich 2018.

${ }^{3}$ A. Morelui/O. Pollicino, "Metaphors, Judicial Frames and Fundamental Rights in Cyberspace", American Journal of Comparative Law, 2020, Available at SSRN: https://ssrn.com/abstract=3422946 p. 26, note 66 quoting Pasquale, "From Territorial to Functional Sovereignty: The Case of Amazon", Law and Political Economy, Dec. 6, 2017, https://lpeblog. org/2017/12/06/from-territorial-to-functional-sovereignty-the-case-ofamazon/

${ }^{4}$ A. TuRINA, Which 'Source Taxation’ for the Digital Economy?, Intertax, v. 46, 6/7, 2018, pp. 495 - 519.

${ }^{5}$ See also, on the so called "Danish cases" of the CJEU [CJEU, Joined cases C-116/16 and joined cases C-115/16]: S. BAERENTZEN, "Danish Cases on the Use of Holding Companies for Cross-Border Dividends and Interest - A New Test to Disentangle Abuse from Real Economic Activity?", World Tax Journal, February 2020, pp. 3- 52. On the Swiss case [Swiss Supreme Court, decision 2C_354/2018 of 20 April 2020] R. DANON, B. MALEK, "Swiss Supreme Court Refers to the CJEU "Danish cases" in Outbound Dividend Case Involving the Swiss-EU Savings Agreement", Kluwer International Tax Blog, July 23, 2020 online at http://kluwertaxblog.com/2020/07/23/swiss-supreme-court-refers-to-the-cjeu-danish-cases-in-outbound-dividend-case-involving-the-swiss-eu-savings-agreement/\# edn5 (13.12.2020).

${ }^{6}$ L. KHAN, “Amazon's antitrust paradox”, The Yale Law Journal, 2017, 126, 3, pp. 564-907; https://www.cnbc.com/2017/12/19/ more-than-75-percent-of-us-online-consumers-shop-on-amazon-most-of- the-time.html. STigler CommitTeE on Digital PlatFORMS, Final Report, September 2019, p.17, available at https://research.chicagobooth.edu/stigler/media/news/committee-on-digital-platforms-final-report.

${ }^{7}$ Two years ago, the OECD/G20 Inclusive Framework approved a "Programme of Work to Develop a Consensus Solution to the Tax Challenges Arising from the Digitalisation of the Economy", OECD 2019, acknowledging the need for and promoting significant reforms of the international tax system via the reallocation of taxing rights and the introduction of a global minimum tax.

${ }^{8}$ See for instance, "Digital Services Act package: Ex ante regulatory instrument for large online platforms with significant network effects acting as gate-keepers in the European Union's internal market", on line at https://ec.europa.eu/info/law/ 
5. Amazon Mechanical Turk (2005), Facebook (opened to the public in 2006), Airbnb (2008), Instagram (2010) and Uber (2011) exert an effective and efficient regulatory control over the terms and conditions for the sale of goods, services and data ${ }^{9}$. The effective power of self-regulation is coupled with that of self-enforcement of the rules. These characteristics create a not inconsiderable difference between a digital platform and a traditional firm, but the former may still only be subject to the legislation drawn up for the latter. The present legal orders, each of which is intended to be sovereign in its own territory; like the Westphalian treaties of 1648, are now increasingly in need of platform collaboration in order to dispense justice. In criminal cases, much of the information necessary for allowing criminal evidence is indisputably out of reach without the collaboration of digital platforms.

6. Trying to access the data stored in a private account, pursuing an offender guilty of deadly revenge porn, or simply trying to implement laws on the protection of privacy or checking if labour standards are being met requires the collaboration of the company which holds and owns the technology that has enabled the wrongful act, the transaction or the service.

7. Against this background, judges and practitioners are left attempting to solve the new legal problems arising in the digital space using private international law rules that were developed in the last two centuries of the previous millennium.

The whole concept of private international law is based on the mechanism of geographical allocation of the problem to be solved. This concept has recently been replaced with that of pursuing universally shared policy goals through private international law. When it is a question of protecting platform users against the platform, the policy goals may differ from those underlying the solving of quaestiones iuris generated by the platform between two users.

\section{Litigation Between Platform Users}

8. The simplest scenario is that of litigation between platform users who have met as a consequence of being "matched" by a platform's algorithm.

9. In all cases where the digital platform has only served to "match" supply and demand, private international law rules do not need to be specifically adapted for the purposes of litigation between users, since the human and social relationship takes place in a given territory and will be subject to its rules.

In other words, the fact that Uber, Airbnb or Taskrabbit is based in a different state from the one in which the contract is fulfilled is irrelevant and does not offer a foreign element sufficient to trigger the need for private international law rules and instruments. Litigation between a passenger and an Uber driver or between a guest and an Airbnb host may be deemed not to have a cross-border element. They will be normally subject to the legal order in which the service is provided ${ }^{10}$.

More complex, and more interesting, are the cases of litigation between users who do not meet in the real world.

These cases involve workers on demand, social media users, online video game players, YouTubers, retailers, etc.

\footnotetext{
better-regulation/have-your-say/initiatives/12418-Digital-Services-Act-package-ex-ante-regulatory-instrument-of-very-largeonline-platforms-acting-as-gatekeepers.

${ }^{9}$ Stigler Report 2019 (note 7), p. 17.

${ }^{10}$ Sullivan v. Oracle Corp., 254 P.3d 237, 247 (Cal. 2011) stating that California labour laws govern work performed in California and that the laws of the states where the platform is based (Arizona and Colorado) could not be referred to to avoid the due payment of overtime work benefitting a California-based employer.
} 


\section{The Importance of Effectiveness and the Role of the Place of Enforcement}

10. One of the first ideas developed to ensure appropriate allocation of a cross-border case was that the entity capable of enforcing its own point of view should impose it ${ }^{11}$.

In the digital space, this principle could justify private enforcement and there are advocates of this simple and liberal solution, especially when it comes to self-regulating systems such as the blockchain ${ }^{12}$. In addition to being a reality and a consequence of a legal vacuum, the power of platforms to impose their own rules has been justified on the grounds that transactions taking place on the platform cannot be anchored to any physical space, especially when automated, as they are in the blockchain or on other platforms which do not play a role of intermediating goods and services.

However, nation states and the European Union are based on constitutional values that represent a major obstacle to this liberal solution.

Classical private international law is therefore still regarded as an unavoidable tool to enable state legislation to be imposed.

11. Drawing on the principle of effectiveness, more flexible criteria have led to the principe de proximite, on the assumption that every cross-border dispute should be allocated to the legal order that is closest to it. Although the closest connection may go beyond a geographical location (the place where the service is provided) and extend to cultural and anthropological proximity (the psychological expectations of the parties, their common language, their belonging to the same society), its identification especially when it takes place ex post - often seems artificial, if not arbitrary.

12. As a consequence, neutral methods of allocation have given way to connecting factors based on shared constitutional values. The most pertinent of these in the digital space are the ones that favour weak parties such as consumers or maintenance creditors in the law-selection process. The same is true of civil compensation for victims of cyber-bullying or other criminal acts.

13. Despite the fact that platform-based social relationships do not necessarily take place in a physical space, viable solutions are provided by the arsenal developed in the last century to identify appropriate connecting factors for human relationships resulting from "matches" created by algorithms.

14. The practical implications of digital relationships do not exist in a realm separate from the real world, and do not escape the laws that govern it within the complex architecture of private international law. In civil and commercial matters, EU private international law regulations are easily adaptable to cyberspace, provided that the place of enforcement is correctly understood and identified.

15. Judges and interpreters are applying the existing Rome I, Rome II and Brussels I bis Regulation to human interactions taking place on the web, which were not affected by, for instance, the recent Regulation (EU) 2019/1150 promoting fairness and transparency for business users of online intermediation services.

It is possible that the same approach will be followed by the Digital Services Act, despite an effort to impose obligations on companies established outside the EU.

It is still uncertain whether these developments will take account of the existing case law, which is already very rich in lessons to be learned.

\footnotetext{
${ }^{11}$ Originally, F. KAHN, Gesetzeskollisionen, Verlag von Duncker \& Humblot, München \& Leipzig, 1928 (1891), pp. 3146 had referred to the expression Näherberechtigung, the closest competence. The idea was then taken up by M. WoLfF, who speaks in this regard of the search for the greatest proximity (der größeren Nahe) and also by W. WENGLER. Traditionally, the principle did not seem to have any significance as regards intangible things that do not have physical existence. Later, a fictitious location even for intangible property was admitted as a kind of analogy. The law of the place of enforcement presents several advantages and, above all, predictability for the creditor (or their assignees) and third parties, in addition to providing effective guarantees to the debtor.

${ }^{12}$ See S. RIVA, "Decentralized Autonomous Organizations (DAOs) in the Swiss Legal Order", Yearbook of Private International Law, Volume 21, 2019/2020, pp. 601-638 and the reference therein.
} 
16. We will first examine cases of patent infringement and secondly cases of defamation.

17. The CJEU was confronted with a case opposing an Austrian-based trader - Wintersteiger and a German on-line advertiser ${ }^{13}$.

Using the advertising platform Google.de, a German advertiser had reserved an "adWord" corresponding to the trademark registered in Austria by a company. As a consequence, users of the search engine wanting to buy the Austrian products of Wintersteiger were directed to the German retailer thanks to the advertisement appearing at the top of the search results in Google.de. The jurisdiction of Austrian courts was difficult to anchor: on the one hand, the damage seemed to be located within the digital search engine Google.de; on the other, the search engine was also accessible from Austria. The CJEU recognised Austrian jurisdiction on the grounds that Austria was both the place where the infringed trademark was registered and the place where the event produced its damaging effects. However, the Court held that the defendant could also be sued in Germany, since the forum damni ex art. 5-3 EU Regulation $44 / 2001$, i.e. the special forum of the Brussels I system, includes the place of establishment of the user of Google AdWords, the author of the damage.

By contrast, no relevance is given to the fact that "the technical display process by the advertiser is activated, ultimately, on a server belonging to the operator of the search engine used by the advertiser". The reason is the lack of foreseeability of a connecting factor based on the location of the server ${ }^{14}$. What is "definite and identifiable, both for the applicant and for the defendant", is the "place of establishment of the advertiser". That place is both the place to which the connecting factor of (the then) Article 5-3 pointed as the place "where the activation of the display process is decided" and the place of enforcement "likely to facilitate the taking of evidence and the conduct of the proceedings".

18. A leading Canadian case concerns prohibition of the distribution of products that infringe a company's intellectual property rights ${ }^{15}$. This is a more delicate case, because the plaintiffs ignored the place of establishment of the company that caused them damage, and, for that reason, court orders could be easily disregarded.

"Despite court orders prohibiting the sale of inventory [the foreign company] continues to carry on its business from an unknown location, selling its impugned product on its websites to customers all over the world".

This being the case, it was clear that Google was the only entity able to enforce the court orders. On the other hand, the search engine's cooperation and compliance were plainly sufficient to put an end to the copyright infringement.

The most appropriate space where the court order could be, and eventually was, successfully enforced was the Google website, a digital space.

19. What lessons can be learned from these two cases?

${ }^{13}$ See CJEU, 19 April 2012, Wintersteiger AG v Products $4 U$ Sondermaschinenbau GmbH, [ECLI:EU:C:2012:220].

${ }^{14} \mathrm{Ibid}$. pt. 36: "It is true that the technical display process by the advertiser is activated, ultimately, on a server belonging to the operator of the search engine used by the advertiser. However, in view of the objective of foreseeability, which the rules on jurisdiction must pursue, the place of establishment of that server cannot, by reason of its uncertain location, be considered to be the place where the event giving rise to the damage occurred for the purpose of the application of Article 5(3) of Regulation No 44/2001". Initially, many voices suggested that a possible head of jurisdiction to attract a tech giant operating globally such as Google to appear before of a forum was the place where its servers were located. However, Google has never disclosed where the servers operating its search engine are, and data can easily be moved from one server to another.

${ }^{15}$ Google v. Equustek 2017 SCC 34. The Supreme Court of Canada upheld an order directing Google to block certain websites so that they did not appear in any Google search results anywhere in the world. The respondent justified the new solution by quoting Newbury J. [Mooney v. Orr (1994), 98 B.C.L.R. (2d) 318 (S.C.)], para. 11: "the courts must, in order to preserve the effectiveness of their judgments, adapt to new circumstances. Such adaptability has always been, and continues to be, the genius of the common law". See G. Clarke, Case Comment Mooney v. ORR, 53 Advocate (Vancouver) 431 (1995). See R. FLEMING, "Google v. Equustek; Jurisdiction over the global internet", https://www.irglobal.com/article/google-v-equustek-jurisdiction-over-the-global-internet/. 
The first lesson is that the location of servers is not a viable connecting factor. Although it is often referred to, and has served in certain decisions, as a connecting factor, data can easily be moved from one server to another, making it difficult to actually trace them.

It is important to stress and focus on the circumstance that in both cases the infringement causing an indemnifiable damage could not have been carried out without the use of the Google platform. It is thus of the essence, for purposes of law enforcement, that Google itself be targeted by judicial orders in order to prevent a perpetuation of the infringement ${ }^{16}$.

20. This solution can be transposed to defamation cases where it is essential for the judiciary to enforce their decisions in the digital space, where the violation occurs. Many people have died around the globe as a result of cyberbullying and revenge porn. Italy is still mourning the suicide of Tiziana Cantone, 31 years old, who was unable to enforce her right to have Facebook and YouTube remove a video taken by her former boyfriend.

21. Private international rules inspired by the need to protect victims of violations carried out in the digital space cannot be limited to enforcement in the place of residence of the victim. The need to make multiple fora available, as a natural consequence of the principle of favor laesi, was already stated by the 2011 eDate judgment of the $\mathrm{CJEU}^{17}$. In many cases it is not necessary or urgent for the victim to receive compensation at home, whereas it is essential and perhaps sufficient to receive compensation on line.

22. De-indexation by Google and/or by the relevant search engine is in fact sufficient to bring these unlawful acts to an end.

\section{Favor Laesi}

23. The principle of favor laesi, already acknowledged by EU private international law, can provide useful guidance on escaping the aterritoriality of cyberspace.

24. The first consequence of the principle is that relevance must be given to the place of establishment of the victim claiming damages. Their place of establishment can serve as a connecting factor in torts committed via the digital platform by users. As the case of Wintersteiger shows, this result is not incompatible with the rules of Brussels I, nor with those of Brussels I bis.

25. A second consequence can lead to the place where the conduct causing the damage occurred. The EU Court of Justice first acknowledged this possibility in the context of the Brussels Convention, but the Rome II Regulation also gives some room to this approach.

As pointed out in Wintersteiger, the law of the country in which the action or the omission that triggered the damage "is decided" can provide a more significant connecting factor for torts and afford better protection for the victim.

26. A place for this approach is explicitly conceded by Article 7 in the case of environmental damages, but it is implicitly authorised in more general terms and for all torts by Article 4 of the Rome

${ }^{16}$ The EU is considering means to institutionalise the role of certain tech firms as gatekeepers. See, e.g., Regulating digital gatekeepers Background on the future digital markets act, on line at "https://www.europarl.europa.eu/RegData/etudes/ BRIE/2020/659397/EPRS_BRI(2020)659397_EN.pdf.

${ }^{17}$ See CJEU, 25 October 2011 eDate Advertising, [ECLI:EU:C:2011:68 ], a case concerning a company based in Austria and operating an Internet portal accessible at the address www.rainbow.at. The plaintiffs were seeking compensation for the alleged infringement of personality rights by means of content placed online on an internet site. The CJEU recalled that, as in Fiona Shevill, C-68/93, ECLI:EU:C:1995:61, compensation for the entire damage suffered by the victim could be brought before the courts of the Member State of the place of establishment of the person who posted that content or before the courts of the Member State in which his centre of interests is situated, whereas the courts of any Member State in the territory of which information placed on the network is or has been accessible could exercise jurisdiction only in respect of the damage occurred in their own legal order. 
II Regulation ${ }^{18}$. According to Article 7 of the Rome II Regulation, the law of "the country in which the event giving rise to the damage occurred" applies as an alternative locus delicti to the one where the damage occurred. ${ }^{19}$ The sole reason for this solution being codified for environmental damages only seems to be connected to the EU institutions' present practice as regards codification of CJEU case law ${ }^{20}$. In other words, since the solution was adopted in 1976 in a case concerning the pollution of the river Rhein, it has become part of the acquis communautaire in relation to environmental damages.

Comparative law offers many examples of this twofold interpretation of the locus damni in favour of the victim - also known as the Günstigkeitsprinzip. In Italy, an optio legis allowing an injured party to base her claim on the law of the place of the harmful event in lieu of the law of the place of the wrongful act was introduced as part of the 1995 reform (Article 62 of the Italian private international law statute) ${ }^{21}$. In Germany, the principle of favor laesi was also part of the 1999 reform (see Article 40(1) EGBGB) $)^{22}$.

\section{A) Favor Laesi in Contract Law}

27. The place of residence of a weaker party may also translate as "the place in which the contract is performed and executed" in all cases where litigation concerns the delivery of goods and the performance of services. Even when the recipient is not a consumer, it will mostly be "at home" that the good is received or the film downloaded (art. 7-1 b Brussels I bis. The residence of the user offers a good compromise: it is "the presumable place of most downloading and platform accesses" and guarantees legal certainty. Unlike what happens in the case of torts, the rules of the Rome I Regulation are less suitable for guaranteeing such an outcome and need revision for the needs of the digital marketplace.

\section{B) Favor Laesi in Crowdworking}

28. Work services provided on line are particularly problematic. It is a recognised fact that microwork platforms - platforms that offer micro-tasks ranging from translation services to homework tutoring etc - risk hiding particularly relevant human rights violations such as child labour or exploitation of workers resulting in severe illnesses ${ }^{23}$. Characterising these violations is problematic in that they may at the same time give rise to tortious and contractual liability.

29. Article $21 \mathrm{~b}$ i) Brussels Ibis seems adequate in the EU context, especially when coupled with Article 8 of the Rome Regulation and its escape clause of Article 4(3). On the more global internet scale, reference to the legal order under which the worker carries out the tasks obtained via the platform may well lead to distortions of the market. On the one hand, this criterion has the advantage of putting the situation of workers employed or "intermediated" by digital platforms on an equal footing with that of their competitors working in the physical market around them.

${ }^{18}$ A. Peter/S. Gless/Ch. Thomale/M.-Ph. Weller, Business and Human Rights: Making the Legally Binding Instrument Work in Public, Private and Criminal Law (26 March 2020). Max Planck Institute for Comparative Public Law \& International Law (MPIL) Research Paper No 06-2020. Available at: https://papers.ssrn.com/sol3/papers.cfm?abstract_id=3561482 accessed 20 November 2020

${ }^{19}$ See I. Pretelli, "La legge applicabile alle obbligazioni non contrattuali nel Regolamento «Roma II»”, in Bonomi (ed.) Diritto internazionale privato e cooperazione giudiziaria in materia civile (Giappichelli 2009) 449 on Art. 7 EU Regulation $864 / 2007$ ss.

${ }^{20}$ The principle was originally set in the context of Handelskwekerij G. J. Bier v. Mines de potasse d'Alsace, 21/76, ECLI:EU:C:1976:166.

${ }^{21}$ L. n. 218/1995.

${ }^{22}$ See J. von HeIn, Das Günstigkeitsprinzip im Internationalen Deliktsrecht, Tübingen, 1999, passim; G. SchmidT, Ehrverletzungen in der elektronischen Presse, Bern, 2020.

${ }^{23}$ See J. Berg/M. Furrers/E. Harmon/U. Ranis/M S. Silberman, Digital labour platforms and the future of work, Towards decent work in the online world, ILO Office, Geneva, 2018. 
30. However, the level of protection of the law of the place "from which the employee habitually carries out his work in performance of the contract" may be very low, thus leading to social dumping, paving the way for unfair competition and creating a race to the bottom. Backroom operations such as content moderation tasks, content-creating, editing, type-setting, call centres and a wide variety of activities that can be performed on line are outsourced to low-labour-standard countries, including India, where educated and skilled workers are available at a significantly lower cost and round the clock.

31. "As a combination of the words "crowd" and "outsourcing" suggest, the word's origins directly refer to the economic motivations for businesses' use of crowdsourcing - cheaper, on-demand labour." ${ }^{24}$ In addition, digital workers find themselves in a self-contained regime where they feel subject to the platform's terms and conditions ${ }^{25}$ even when they perform the tasks for another user. Recent case law shows that private ordering is unable to provide the protection that states grant to workers in the relationship with their employer or client. Such relationships are always governed by a law, to be identified through private international law.

32. In line with the recent initiatives on Human Rights Due Diligence ${ }^{26}$, destination-based labour standards would appear to be the most appropriate way of preventing negative externalities and ensuring greater consistency across the digital society in which these workers operate. This article suggests that the law applicable to crowdwork should be the law of the place where the client/employer is based. This would guarantee fairer competition that is favourable to social progress. Firstly, this would equalise the conditions and prices of services in a given market and neutralise social dumping. Secondly, it would increase the appeal of platform work in countries such as India, thus favouring a race to the top. The change may seem radical but once placed in the context of the "digital revolution" it could turn out to be the simplest natural consequence and appropriate legal reaction to the digitalisation of work.

\section{Relations Between a User and a Platform Exercising Decisive Control}

Private international law problems arising between a platform user and the platform itself should also be solved with an eye to the imbalance between the two parties, thus granting enhanced protection to the weaker one.

\section{When the Platform Exercises Decisive Control}

33. Recently, the Court of Justice has given a provisional solution to the problem of defining the employment status of chauffeurs working via affiliation with a platform. Up to now there has been no consistency across national courts as to the definition of gig workers: some decisions have recognised their subordinate status, others denied it and still others have considered them to be a mixture of the two.

34. The digital platform's role in the organisation of the service ${ }^{27}$ is considered decisive in characterising the gig workers providing that service.

${ }^{24}$ J. Berg/M. Furrers/E. Harmon/U. Ranis/M S. Silberman, Digital labour platforms and the future of work, Towards decent work in the online world, ILO Office, Geneva, 2018, p. 3.

${ }^{25}$ Ibidem, at $22 \mathrm{ff}$.

${ }^{26}$ M. A.Cherry, , A Global System of Work, A Global System of Regulation?: Crowdwork and Conflicts of Law. Tulane Law Review, Vol. 94, 2019, Saint Louis University School of Law Legal Studies Research Paper No. 2019-11, Available at SSRN: https://ssrn.com/abstract=3523303

${ }^{27}$ See also CJEU, 12 July 2011, L'Oréal SA et al. v eBay International AG et al., [ECLI:EU:C:2011:474] distinguishing, pt. 113, "the case where the service provider plays an active role of such a kind as to give it knowledge of, or control over, those data (Google France and Google, paragraphs 114 and 120)" from the case where the service provider confines "itself to providing that service neutrally by a merely technical and automatic processing of the data provided by its customers". 
35. A case where "the service at issue in the main proceedings merely enables... the activity consisting in putting persons wishing to make a journey in the urban area in contact only with licensed taxi drivers whose activity pre-exists and for whom that intermediation service constitutes only one method, among others, of obtaining customers, which, moreover, they are in no way obliged to use" is an information society service within the meaning of Article 1(2) of Directive 98/34/EC as amended by Directive 98/48/EC ${ }^{28}$.

36. This situation is clearly differentiated from that of "the intermediation service" at issue in the case giving rise to the judgment of 20 December 2017, Asociación Profesional Elite Taxi (C-434/15, EU:C:2017: 981), which created and made accessible the provision of travel services in the urban area by non-professional drivers who had previously been absent from the market. In the case of Uber, the treatment of drivers will eventually lead to their characterisation as employees ${ }^{29}$.

37. Characterisation influences the applicable rules on jurisdiction. An employee has the benefit of the choice granted by art. 21, Brussels I bis, allowing him to sue the employer in the forum rei or in the place where the work is carried out (or in the last place where work was carried out). If these two options point to more than one place (for instance when the employee travels for work), the special forum is in the place where the business that engaged the employee is or was situated.

38. The choice of forum is regulated by the relevant rule of Article 23 Brussels Ibis which provides that choice of forum agreements may only be concluded a posteriori, "after the dispute has arisen" (unless the agreements may only favour them).

39. The CJEU and national courts have used these principles to re-establish an egalité des armes in platform-related litigation without impairing the attractiveness of the European market place.

The only limits to the protection of the weak party in the European system derive from the principle of legal certainty, whereby foreseeability of the forum and of the applicable law by the platform must be ensured.

40. In most cases, the courts of the employee's place of domicile will apply the lex fori as a consequence of the Rome I Regulation.

The Regulation lists, as connecting factors for employees: "the law of the country in which or, failing that, from which the employee habitually carries out his work in performance of the contract" (art.8-2), and the country where the place of business through which the employee was engaged is situated (art. 8.3). Even though workers may choose a different law (art.8-1), or be subject to it by virtue of the escape clause (art. 84), in the majority of cases workers will be able to litigate "at home" and can expect the "home" labour standards to govern their relationship with their employers.

\section{When the Platform Does not Exercise Decisive Control}

41. In another hypothesis, as affirmed by the CJEU in the case Airbnb Ireland ${ }^{30}$, the platform is considered to be a simple intermediary.

\footnotetext{
${ }^{28}$ CJEU, 3 December 2020, Star Taxi App SRL, [ECLI:EU:C:2020:980].

${ }^{29}$ CJEU, 20 December 2017, Asociación Profesional Elite Taxi [EU:C:2017: 981] and CJEU, 10 April 2018, Uber France SAS v Nabil Bensalem, [ECLI:EU:C:2018:221].

30 See CJEU, 19 December 2019 [ECLI:EU:C:2019:1112] pts. 57 "As such, it follows that an intermediation service such as the one provided by Airbnb Ireland cannot be regarded as forming an integral part of an overall service, the main component of which is the provision of accommodation"; 65 "the rules for the functioning of an intermediation service such as the one provided by Airbnb cannot be equated to those of the intermediation service which gave rise to the judgments of 20 December 2017, Asociación Profesional Elite Taxi (C434/15, EU:C:2017:981, paragraph 39), and of 10 April 2018, Uber France (C320/16, EU:C:2018:221, paragraph 21)"; 69 "an intermediation service which, by means of an electronic platform, is
} 
42. The European Commission in its "European agenda for the collaborative economy" uses the following criteria to assess the decisiveness of the platforms' control:

"(1) Price: does the collaborative platform set the final price to be paid by the user, as the recipient of the underlying service. Where the collaborative platform is only recommending a price or where the underlying services provider is otherwise free to adapt the price set by a collaborative platform, this indicates that this criterion may not be met.

(2) Other key contractual terms: does the collaborative platform set terms and conditions, other than price, which determine the contractual relationship between the underlying services provider and the user (such as for example setting mandatory instructions for the provision of the underlying service, including any obligation to provide the service).

(3) Ownership of key assets: does the collaborative platform own the key assets used to provide the underlying service." 31

Once it is established that the platform is not per se an employer but a mere intermediary, a distinction must be made between cases involving consumers and cases involving businesses.

43. Is it really so?

Some scholars have cast doubt on the legitimacy of making a distinction between business-toconsumer (B2C) and business-to-business (B2B) relationships when the counterparty is a tech giant ${ }^{32}$.

Ebay 'power sellers' and 'Airbnb landlords' are professional platform users that may certainly be considered to have a B2B relationship with the platform, but what about the small and medium companies obliged to use the platform to survive in the market?

44. This doubt has reached the Court of Justice in a case that pits a German company that runs hotels against the platform booking. $\mathrm{com}^{33}$.

The importance of booking.com has reached such a scale that no hotel can possibly avoid being a platform user.

Booking.com has offices in 70 countries, employs 17,000 workers and manages the booking of over 1.6 million overnight stays every 24 hours. It has over 28 million listings across 228 countries and is available in 43 languages $^{34}$.

When they agree to display their establishment on the platform, professional users are subject to the following clause "Save as set out otherwise in this Agreement, this Agreement shall be exclusively governed by and construed in accordance with the laws of the Netherlands". This clause concerns solely B2B relations and has recently been challenged before the Court of Justice of the European Union.

A German company that operates a hotel in Schleswig-Holstein (Germany) has assumed that the continuous modification - to the advantage of booking.com - of the general conditions of the platform's B2B contracts is an infringement of fair competition law. Basing its claim on German competition law, the German company has seized the Landgericht Kiel (Kiel Regional Court, Germany). In that context,

intended to connect, for remuneration, potential guests with professional or non-professional hosts offering short-term accommodation services, while also providing a certain number of services ancillary to that intermediation service, must be classified as an 'information society service' under Directive 2000/31".

${ }^{31}$ Communication from the Commission to the European Parliament, the Council, the European Economic and Social Committee and the Committee of the Regions, A European agenda for the collaborative economy, $\{\operatorname{SWD}(2016) 184$ final $\}$ Brussels, 2.6.2016, $\mathrm{COM}(2016) 356$ final.

32 P. Franzina, "Promoting Fairness and Transparency for Business Users of Online Platforms: The Role of Private International Law, in I. PRETELLI (ed), Conflict of laws in the maze of digital platforms/Le droit international privé dans le labyrinthe des plateformes digitales, Actes de la 30e Journée de droit international privé du 28 juin 2018 à Lausanne, Zurich 2019, p. 147 et seq.;

${ }^{33}$ The case is extensively presented by P. FAVROD-Coune, "The legal position of the weaker party in B2B relationships with online platforms in the European Union, an analysis of dispute resolution mechanisms in Regulation (EU) 2019/1150", Yearbook of Private International Law, Volume 21, 2019/2020, pp. 523-548.

${ }^{34}$ Ibidem. 
the German company has claimed that it is forced to enter into contracts with booking.com because of the latter's dominant position on the market and has asked that its unfair practices, which plainly constitute an abuse of a dominant position, be declared contrary to competition law; the German company has therefore asked the judge to order booking.com to refrain from continuing such practices. Again, enforcement is sought on the platform itself.

45. On 24 November 2020 the CJEU stated that Article 7(2) of the Brussels I bis Regulation applies "to an action seeking an injunction against certain practices implemented in the context of the contractual relationship between the applicant and the defendant, based on an allegation of abuse of a dominant position by the latter in breach of competition law"35.

The judgment adheres to the AG opinion delivered in September 2020 and clearly reverses the earlier Brogsitter judgment ${ }^{36}$, which could have allowed the cause of action based on delict to fall under the concept of 'matter relating to contract' within the meaning of Article 7(1), since the action concerns a harmful event that also constitutes a breach of a contractual obligation.

In addition, the court fails to give relevance to the weakness of one of the Bs in the B2B contract.

46. It is increasingly apparent that small and medium businesses require protection similar to that of consumers in cross-border disputes with a digital platform.

Activities such as "publishing books, lecturing, operating websites, fundraising" have already been declared not inconsistent with the notion of consumer, since the contracting parties' relationship continues to be characterised by substantial inequality of bargaining strength ${ }^{37}$.

47. It is fair enough to wonder whether, in the future, the protection granted to consumers by art. 18 of EU Regulation 1215/2012, offering a choice between the courts of the Member State of the consumer's domicile and the forum rei, should not be extended to "weak parties" as compared to "strong" ones, which by virtue of their strength may easily defend themselves in the forum actoris - i.e. the domicile of the weaker one ${ }^{38}$.

48. The prohibition of clauses creating a "significant imbalance" could be aimed not only at protecting consumers in B2C contracts but also at fair competition in B2B contracts, since this category of mandatory rules may well include forum and law selection clauses that substantially erode consumers' access to justice.

49. In a case concerning Facebook, the Paris Appellate Court affirmed French jurisdiction and decided on the merits of a case between the platform Facebook and one of its users, who was domiciled in France: "Les difficultés pratiques et le coût d'accès aux juridictions californiennes sont de nature à

\footnotetext{
${ }^{35}$ See CJEU, 24 November 2020, Wikingerhof GmbH \& Co. KG v Booking.com BV, [ECLI:EU:C:2020:950].

${ }^{36}$ See CJEU, 13 March 2014, Brogsitter, [ EU:C:2014:148], pt. 18 and also CJEU, 14 July 2016, Granarolo SpA contre Ambrosi Emmi France SA [ECLI:EU:C:2016:559] stating that Article 5(3) of the Brussels I Regulation (EC) No 44/2001 of 22 December 2000 means that "an action for damages founded on an abrupt termination of a long-standing business relationship, such as the termination at issue in the main proceedings, is not a matter relating to tort, delict or quasi-delict within the meaning of that regulation if a tacit contractual relationship existed between the parties, a matter which is for the referring court to ascertain. Demonstration of the existence of a tacit contractual relationship of that kind must be based on a body of consistent evidence, which may include in particular the existence of a long-standing business relationship, the good faith between the parties, the regularity of the transactions and their development over time expressed in terms of quantity and value, any agreements as to prices charged and/or discounts granted, and the correspondence exchanged."

${ }^{37}$ CJEU, 25 January 2018, Maximilian Schrems v Facebook Ireland Limited [ECLI:EU:C:2018:37] pt. 41 "activities of publishing books, lecturing, operating websites, fundraising and being assigned the claims of numerous consumers for the purpose of their enforcement do not entail the loss of a private Facebook account user's status as a 'consumer' within the meaning of that article".

${ }^{38}$ Cp. P. Franzina (note 29), p. 149, regretting that Regulation of the European Parliament and of the Council(EU) $2019 / 1150$ on promoting fairness and transparency for business users of online intermediation services applicable as of 20 July 2020 does not contain any specific protective provisions on private international law.
} 
dissuader le consommateur d'exercer toute action devant les juridictions concernant l'application du contrat et à le priver de tout recours à l'encontre de la société Facebook Inc; qu'à l'inverse, cette dernière a une agence en France et dispose de ressources financières et humaines qui lui permettent d'assurer sans difficulté sa représentation et sa défense devant les juridictions françaises" ${ }^{39}$.

The authors of the decisions give relevance to the significant imbalance (désequilibre significatif) between the resources of the platform and those of its users.

Similar words are used by the Supreme Court of Canada, with reference to the gross inequality of bargaining power as the main reason for not enforcing a forum selection clause between Facebook and one of its users. ${ }^{40}$

\section{Some Conclusions}

50. If appropriately adapted, private international rules have already offered well-shaped solutions in most digital litigation cases, especially as regards connecting factors available for torts within the EU.

51. Connecting factors serve all the functions of private international law: allocating jurisdiction, identifying the applicable law, as well as serving as vectors for the recognition and enforcement of decisions and acts.

52. In cases pitting platform users against each other, the most reliable guiding principles are the principle of effectiveness and that of favor laesi.

Wider application of favor laesi is being promoted in order to allow persons who have suffered harm as a result of using digital platforms to benefit from the Günstigkeitsprinzip - if necessary through an adaptation of the exception clause in the Rome II Regulation.

A series of successful cases has been decided - on the basis of these principles - by fora actoris, and most of them have required (compulsory) collaboration by digital platforms in allowing enforcement of court decisions in cyberspace itself.

Digital platforms have represented the relevant area of enforcement in most cases of litigation between platform users, because de-indexation - or similar platform adjustments - are often both necessary and sufficient to put an end to the damage.

53. In the long run, enhanced protection of persons entering into on-line contracts will eventually have to be recognised through an extension of the principle of favor laesi to suppliers of work services, by analogy with the most recent development of human rights due diligence.

In this context, standard protection clauses leading to destination-based labour standards, when promoted by an international organisation such as the ILO, would represent a major advancement ${ }^{41}$.

The same principle may provide guidance with regard to litigation pitting a user against the platform in every situation where there is a need to redress the significant imbalance of power between the digital platform and the average business person.

54. The financial and human resources available do not enable the parties to represent and defend themselves on an equal footing before foreign courts. Business users, often forced to use the platform to survive in their own marketplace, may not always be equipped with the armoury they need to defend themselves on equal terms before the jurisdiction selected on the basis of the choice-of-forum standard clause imposed by the platform on the assumption that it concerns peer-to-peer relations.

\footnotetext{
${ }^{39}$ Cour d'appel de Paris, 12 Février 2016, (n 2016-58, 6 pages).

${ }^{40}$ Douez v. Facebook, Inc., 2017 SCC 33, [2017] 1 S.C.R. 751.

${ }^{41}$ See I. Pretelli, "Improving Social Cohesion through Connecting Factors in the Conflict of Laws of the Platform Economy", in Conflict of laws in the maze of digital platforms (note 29), pp. 46-47.
} 